\title{
REFORMULASI STRATEGI UNTUK MENINGKATKAN BUDAYA KESELAMATAN KERJA DI PT XYZ
}

\author{
STRATEGY REFORMING TO INCREASE SAFETY CULTURE AT PT XYZ
}

\author{
Tujuan Sanggam Silaen ${ }^{* 1}$, Lukman M Baga ${ }^{* *}$, dan KirBrandoko ${ }^{* * *}$ \\ *) PT Pertamina EP \\ Gedung Standard Chartered, Jalan Prof Dr. Satrio No, 164 Jakarta Selatan \\ ${ }^{* *}$ Departemen Agribisnis, Fakultas Ekonomi dan Manajemen, Institut Pertanian Bogor \\ Jl. Kamper Kampus IPB Darmaga, Bogor 16680 \\ ${ }^{* * *)}$ Pascasarjana Universitas Ibn Khaldun \\ Jl. K.H. Sholeh Iskandar Km. 2 Bogor 16162
}

\begin{abstract}
Upstream oil and gas sector has the characteristics of high-cost, high-tech and highrisk, and safety of operations. PT XYZ is a national company operating in the upstream oil and gas sector with operations spreading across Indonesia. This study aimed to evaluate the achievement of the current safety culture of the company, to analyze the behavioral factors that influenced safety culture and to redefine the strategy to improve the safety culture to minimize the occurrence of accidents. The research method used in the study included validity test and Reliability test, descriptive analysis, gap analysis and SEM analysis (Structural Equation Modelling). The results of the gap analysis show that safety culture in PT XYZ has not met the expectations. The results of the SEM analysis showed behavioral factors significantly influenced the safety culture. The combination between gap analysis and SEM Analysis showed that the strategies that should be carried out by PT XYZ in improving safety culture include strengthening the management commitment for safety, ensuring the process of investigation conducted objectively, maintaining the program rewards and consequences, writing safety aspects in the job description and job responsibilities and individual performance criteria, strengthening employee competence in occupational safety, intensifying communication of occupational safety aspects, analyzing workload and ensuring adequacy of the personnel number and application of SWA (stop work authority).
\end{abstract}

Keywords: oil and gas, safety culture, SEM

\begin{abstract}
Abstrak: Sektor hulu minyak dan gas bumi (migas) memiliki karakteristik berbiaya tinggi, berteknologi tinggi dan berisiko tinggi, salah satunya risiko keselamatan operasi. PT XYZ merupakan perusahaan nasional yang bergerak di sektor hulu migas dengan wilayah operasi tersebar di seluruh Indonesia. Penelitian ini bertujuan untuk mengevaluasi pencapaian budaya keselamatan kerja PT XYZ saat ini, menganalisis faktor perilaku yang memengaruhi budaya keselamatan kerja dan merumuskan kembali strategi meningkatkan budaya keselamatan kerja sehingga dapat meminimalkan terjadinya kecelakaan kerja. Metode penelitian yang digunakan dalam penelitian adalah uji validitas dan reabilitas, analisis deskriptif, analisis gap dan analisis SEM (Structural Equation Modelling). Hasil gap analisis menunjukkan budaya keselamatan kerja di PT XYZ belum memenuhi harapan. Hasil analisis SEM menunjukkan faktor perilaku berpengaruh signifikan terhadap budaya keselamatan kerja. Kombinasi dari gap analisis dan analisis SEM menunjukkan strategi yang harus dilakukan oleh PT XYZ dalam meningkatkan budaya keselamatan kerja melalui penguatan komitmen manajemen dalam aspek keselamatan kerja, memastikan proses investigasi dilakukan secara objektif, mempertahankan program penghargaan dan konsekuensi, memasukkan aspek keselamatan kerja dalam uraian tugas dan tanggung jawab jabatan dan penilaian kinerja individu, penguatan kompetensi keselamatan kerja, komunikasi aspek keselamatan kerja yang lebih intensif, analisis beban kerja dan kecukupan jumlah personil dan penerapan SWA (stop work authority).
\end{abstract}

Kata kunci: minyak dan gas bumi, budaya keselamatan kerja, SEM

\footnotetext{
${ }^{1}$ Corresponding author:

Email: tujuan96@yahoo.com
} 


\section{PENDAHULUAN}

Sektor hulu minyak dan gas bumi (migas) merupakan sektor yang menyumbang penerimaan bagi negara Republik Indonesia. Dalam kurun waktu tahun 20092014 sektor hulu migas telah berkontribusi bagi negara Republik Indonesia lebih dari USS 27 milyar/tahun (SKK Migas, 2016). Industri hulu minyak dan gas bumi (migas) memiliki karakteristik berbiaya tinggi, berisiko tinggi dan berteknologi tinggi. Salah satu aspek dalam risiko kegiatan industri hulu minyak dan gas bumi adalah keselamatan operasi migas.

Setiap kecelakaan akan mengakibatkan timbulnya biaya. Oleh sebab itu, perusahaan berupaya semaksimal mungkin untuk melakukan upaya pencegahan sehingga tidak terjadi insiden. Implementasi keselamatan kerja yang baik diharapkan dapat menurunkan tingkat kecelakaan kerja dan dapat meningkatkan produktivitas kerja karena indeks kompetitif dari suatu negara berbanding terbalik dengan laju insiden kecelakaan kerja dan Indonesia termasuk negara yang indeks kompetetif rendah (Takala et al. 2012).

PT XYZ merupakan salah satu perusahaan yang bergerak di sektor hulu migas dengan wilayah operasi yang tersebar di seluruh Indonesia, mulai dari Provinsi Nangroe Aceh Darussalam sampai ke Provinsi Papua. PT XYZ merupakan salah satu KKKS (Kontraktor Kontrak Kerja Sama) migas. Sebagai salah satu perusahaan yang berusaha di sektor hulu migas, PT XYZ menyadari bahwa pengelolaan keselamatan operasi merupakan hal yang mutlak harus dilakukan dan merupakan KPI (Key Performance Indikator) mulai dari direksi sampai ke level pekerja operasional. Perusahaan telah melakukan upaya-upaya untuk dapat mencapai kinerja keselamatan kerja yang baik, antara lain melalui pemberian pelatihan, penyediaan peralatan dan material yang sesuai standar dan penerapan sistem manajemen keselamatan dan kesehatan kerja dan lindungan lingkungan (Pertamina EP, 2016). Selain itu telah diberlakukan mekanisme pemberian penghargaan terhadap personil terhadap upaya-upaya positif dalam aspek keselamatan kerja dan pemberian konsekuensi terkait dengan pencapaian kinerja keselamatan kerja yang kurang menggembirakan.

Meskipun demikian, perusahaan telah melakukan upaya-upaya tersebut. Namun, kecelakaan kerja masih terus terjadi. Hal ini menunjukkan implementasi aspek keselamatan kerja masih belum terimplementasi dengan baik. Hasil investigasi internal, ditemukan fakta $63 \%$ penyebab langsung dari insiden disebabkan oleh perilaku tidak aman dan $37 \%$ disebabkan oleh kondisi tidak aman. Faktor manusia ini sangat berkaitan dengan perilaku dari personil dan peranan manajemen dalam menumbuhkan budaya keselamatan kerja di organisasi. Berdasarkan informasi tersebut diatas diperkirakan budaya keselamatan kerja di PT XYZ masih belum maksimal, yang ditandai dengan masih tingginya kejadian kecelakaan kerja. Oleh sebab itu, perlu dilakukan penelitian mengenai budaya keselamatan kerja saat ini dan faktor-faktor yang memengaruhi budaya keselamatan kerja sehingga dapat dilakukan upaya perbaikan untuk meningkatkan kinerja keselamatan kerja. Hal ini didukung oleh penelitian Havold (2010) yang menyimpulkan pengukuran budaya keselamatan kerja dapat menjadi alat bantu perusahaan dalam mencegah kecelakaan kerja karena memberikan informasi mendalam tentang budaya keselamatan kerja yang yang dapat dipergunakan oleh perusahaan dalam merencanakan dan melaksanakan perbaikan kinerja keselamatan.

Budaya keselamatan kerja pada organisasi adalah produk dari nilai-nilai, sikap, persepsi, kompetensi dan pola perilaku dari individu dan kelompok dalam organisasi tersebut yang menentukan komitmen, gaya dan kemampuan dari manajemen kesehatan dan keselamatan dalam organisasi (Mineral Council of Australia, 1999). Menurut Gibson et al. (1996) budaya di dalam organisasi merupakan kepribadian dan perasaan organisasi serta memengaruhi cara pekerja dalam menyelesaikan pekerjaan. Budaya ini harus terintenalisasi ke dalam setiap personil di perusahaan sehingga menjadi level penerapanan keselamatan kerja bertransformasi dari level reactive menjadi interdependent dan menjadi perilaku organisasi. Hal ini sejalan dengan penelitian Fabio et al. (2016) dan yang menemukan bahwa komitmen organisasi sangat berpengaruh terhadap kinerja karyawan dan penelitian dari Amirah et al. (2013) yang menunjukkan komitmen dari seluruh pihak di dalam organisasi dibutuhkan untuk menciptakan budaya keselamatan kerja. Proses internalisasi budaya keselamatan kerja dapat dipercepat dengan melaksanakan fungsi manajerial. Manajerial melalui fungsi perencanaan, perngorganisasian, pengarahan dan pengendalian dapat mengubah budaya dan hal ini harus dilaksanakan secara konsisten (Gibson et al. 1996). Hal ini diperkuat oleh hasil penelitian 
Boughaba et al. (2014) yang menemukan bahwa komitmen manajemen berpengaruh signifikan terhadap budaya keselamatan.

Menurut Geller (2001) budaya keselamatan kerja dipengaruhi oleh tiga faktor, antara lain: faktor lingkungan, faktor personal dan faktor perilaku. Faktor perilaku berpengaruh penting dalam pembentukan budaya keselamatan kerja. Hal ini didukung oleh data statistik kecelakaan kerja di PT XYZ yang menunjukkan mayoritas penyebab kecelakaan kerja adalah faktor perilaku. Penelitian yang dilakukan Sialagan (2008) menemukan hubungan yang signifikan antara faktorfaktor pengetahuan, motivasi, persepsi perilaku aman, peranan rekan kerja dan peranan pengawas terhadap perilaku aman. Hal ini sesuai dengan penelitian Kristanto et al. (2017) yang menunjukkan kompetensi pekerja juga memegang peranan penting dalam meningkatkan kinerja keselamatan kerja. Hal ini diperkuat oleh penelitian DeSarbo et al. (2007) yang juga menemukan kesimpulan sama, bahwa sumber daya manusia merupakan komponen penting dalam menciptakan keunggulan bersaing.

Penelitian ini bertujuan mengevaluasi pencapaian budaya keselamatan kerja PT XYZ saat ini, menganalisis faktor perilaku yang memengaruhi budaya keselamatan kerja dan merumuskan kembali strategi untuk meningkatkan budaya keselamatan kerja sehingga dapat meminimalkan terjadinya kecelakaan kerja. Peneliti membatasi penelitiannya pada salah satu wilayah operasi PT XYZ, dengan mempertimbangkan wilayah operasi PT XYZ yang luas dan terjadinya beberapa kali insiden kecelakaan kerja dengan kategori berat dan meninggal dunia di field tersebut pada periode 2010 - 2015. Penelitian pada lapangan tersebut fokus pada identifikasi faktor-faktor perilaku yang memengaruhi budaya keselamatan kerja.

\section{METODE PENELITIAN}

Penelitian ini dilaksanakan di Field R, salah satu Field PT XYZ, yang berada di provinsi Nangroe Aceh Darussalam pada bulan Agustus 2016 hingga bulan Desember 2016.

Penelitian ini menggunakan pendekatan metode deskriptif dan studi kasus. Penelitian dengan menggunakan metode deskriptif bertujuan memberikan gambaran tentang sesuatu yang sedang berlangsung pada saat penelitian serta mendeskripsikan secara tepat mengenai fakta-fakta serta hubungan antar fenomena yang diteliti (Nazir, 1988). Penelitian ini dilakukan dengan menggunakan metode studi kasus yang menghendaki suatu kajian yang rinci, mendalam dan menyeluruh atas obyek tertentu yang biasanya relatif kecil selama kurun waktu tertentu.

Penelitian ini mengunakan data primer menggunakan kuesioner dengan skala likert. Skala likert mengukur tingkat persetujuan atau ketidaksetujuan responden terhadap serangkaian pernyataan yang mengukur suatu obyek (Istijanto, 2005). Skala ini umum digunakan dalam kuesioner dan merupakan skala yang paling banyak digunakan dalam penelitiaan atau riset survei. Peneliti menggunakan kuosioner berisi pertanyaan dengan lima pilihan sikap, dimulai dengan angka satu sampai dengan angka lima ( $1=$ sangat tidak setuju, $2=$ tidak setuju, $3=$ ragu-ragu, $4=$ setuju, dan $5=$ sangat setuju). Penggunaan skala Likert dengan lima pilihan alternatif dan berskala ganjil agar dapat menampung kategori yang netral dan tidak membingungkan responden dalam memilih (Aisah, 2011). Jumlah responden survei adalah 73 orang pekerja PT XYZ di Field $\mathrm{R}$ yang tersebar di beberapa bagian, antara lain operasi produksi, petroleum engineering, workover $\&$ well services, pemeliharaan, health safety security and environment, keuangan, legal \& relation, human resources, supply chain and general services. Jumlah responden ini sudah memenuhi ketentuan minimal responden karena dalam analisis Structural Equation Modeling (SEM) jumlah responden minimal adalah 5 responden untuk setiap indikator sehingga dengan jumlah indikator sebanyak 12 maka dibutuhkan minimal jumlah sampel adalah 60 (Ferdinand, 2002). Metode penarikan sampel pada penelitian ini adalah dengan menggunakan metode sampling dan tergolong ke dalam proportional stratified random sampling, karena populasi dibagi-bagi atas beberapa strata dan masing-masing strata diambil sampelnya. Penyebaran kuesioner akan dilakukan dengan metode offline. Kuesioner akan dikirim secara langsung sesuai alamat yang sudah diinformasikan responden sebelumnya. Sebelum kuosioner dikirim ke responden maka dilakukan pengujian validitas dan reabilitas.

Penelitian ini juga menggunakan data sekunder, antara lain: studi pustaka, data-data penunjang di PT XYZ serta artikel, jurnal, dan buku-buku yang relevan dengan topik penelitian. 
Teknik pengolahan dan analisis data terdiri dari uji validitas dan reabilitas, analisis deskriptif, analisis gap dan untuk menguji hipotesis yang diajukan digunakan teknik analisis SEM yang dioperasikan melalui program Linear Structural Relationship (LISREL).

\section{Uji Validitas dan Reliabilitas}

Uji validitas dan reliabilitas merupakan langkah awal yang dilalui peneliti untuk menguji apakah kuesioner sudah layak atau tidak untuk disebar (Zulganef, 2006). Uji validitas dilakukan menggunakan skor tiap item dengan total skor. Teknik korelasi yang digunakan adalah Pearson Product Moment, dimana instrument dikatakan valid apabila nilai korelasinya (r) lebih besar dibandingkan dengan (r) tabel. Uji validitas dalam penelitian ini dilakukan menggunakan program SPSS 22.0 dan menggunakan jumlah sample sebanyak 30 . Sedangan untuk nilai reliabilitas diukur dengan nilai cronbach alpha dengan nilai minimum 0,70 .

\section{Gap Analisis}

Gap analisis dilakukan untuk mengetahui gap antara budaya keselamatan kerja saat ini dengan budaya keselamatan kerja yang diharapkan. Analisis dilakukan dengan mengurangi skor rata-rata dari setiap pertanyaan dalam kuesioner budaya keselamatan kerja saat ini dengan skor rata-rata dari setiap pertanyaan dalam kuesioner budaya keselamatan kerja yang diharapkan.

\section{Analisis SEM}

Analisis SEM dipergunakan untuk menguji hipotesis penelitian dan menganalisis hubungan antara faktor perilaku dan budaya keselamatan kerja. Menganalisis model penelitian dengan SEM dapat mengidentifikasi dimensi-dimensi sebuah konstruk dan pada saat yang sama mengukur pengaruh atau derajat hubungan antar faktor yang telah diidentifikasi dimensi-dimensinya (Ferdinand, 2002).

Guna mengetahui hubungan antara faktor perilaku sebagai variabel eksogen dengan budaya keselamatan kerja sebagai variabel endogen maka dapat disusunlah kerangka pemikiran penelitian yang dapat dilihat pada gambar satu. Variabel eksogen memiliki lima dimensi, yakni: pengetahuan, motivasi, persepsi, peran rekan kerja dan peran pengawas (Sialagan, 2008). Variabel endogen terdiri dari tujuh dimensi (Kines et al. 2011), yakni komitmen, kompetensi dan prioritas manajemen terhadap keselamatan; pemberdayaan keselamatan oleh manajemen; keadilan manajemen; komitmen pekerja atas keselamatan; prioritas keselamatan dan risiko yang tidak dapat diterima oleh pekerja; komunikasi, pembelajaran aspek safety antar pekerja dan keyakinan pekerja akan keberhasilan sistem manajemen keselamatan. Model penelitian yang digunakan dalam penelitian ini adalah model struktur berjenjang dengan hipotesis penelitian sebagai berikut:

H0 : Faktor perilaku, yang terdiri dari pengetahuan, motivasi, persepsi, peran rekan kerja dan peran pengawas tidak berpengaruh positif dan signifikan terhadap budaya keselamatan kerja.

H1 : Faktor perilaku, yang terdiri dari pengetahuan, motivasi, persepsi, peran rekan kerja dan peran pengawas berpengaruh positif dan signifikan terhadap kinerja pegawai.

\section{HASIL}

Hasil uji validitas dan reliabilitas

Hasil uji validitas dan reliabilitas, diperoleh nilai $r$ hitung atau korelasi lebih besar dari $\mathrm{r}$ tabel untuk $\mathrm{n}=30$ dengan alpha $5 \%$ sebesar 0,361 sehingga semua pertanyaan valid. Nilai alpha cronbach lebih besar dari cut value 0,70 maka dikatakan reliable. Sehingga dapat disimpulkan bahwa pertanyaan sudah mampu mengukur variabel dan responden secara konsisten mampu menjawab pertanyaan dengan baik.

\section{Karakteristik responden}

Responden pada penelitian ini adalah pekerja di field $\mathrm{R}$. Karakteristik responden diklasifikasikan berdasarkan demografinya, yakni jabatan, usia, jenis kelamin, pengalaman kerja, dan pendidikan. Jumlah sampel sebanyak 73 orang. Adapun karakteristik responden berdasarkan informasi demografinya diuraikan pada Tabel 1.

Evaluasi pencapaian budaya keselamatan kerja PT $\mathrm{XYZ}$

Gap analisis membandingkan antara rata-rata budaya keselamatan kerja saat ini dan budaya keselamatan kerja yang diharapkan. Jika bernilai negatif artinya budaya keselamatan kerja saat ini masih dibawah harapan, jika bernilai positif artinya nilai budaya keselamatan kerja saat ini lebih tinggi dari harapan. 
Gap analisis menunjukkan bahwa budaya keselamatan kerja saat ini masih belum memenuhi harapan dengan indikator nilai rata-rata setiap pernyataan budaya keselamatan kerja saat ini masih lebih kecil dari nilai rata-rata budaya keselamatan kerja yang diharapkan. Pencapaian budaya keselamatan kerja ini sejalan dengan kinerja keselamatan saat ini karena kecelakaan kerja masih sering terjadi. Hal ini sejalan dengan penelitian yang dilakukan Khdair et al. (2011) yang menemukan bahwa komitmen manajemen, pelatihan, penghargaan dan leadership berpengaruh terhadap kinerja keselamatan. Studi yang dilakukan Hee et al. (2014) juga menunjukkan bahwa budaya yang baik di organisasi akan memberikan kinerja keselamatan yang baik dan budaya keselamatan kerja merupakan bagian dari budaya organisasi.

Hasil gap analisis menunjukkan bahwa manajemen sangat berperan dalam budaya keselamatan kerja. Hal ini ditandai dengan tujuh pernyataan yang terkait dengan komitmen manajemen masuk ke dalam sepuluh pernyataan dengan gap tertinggi. Oleh sebab itu, pembenahan komitmen manajemen harus menjadi prioritas untuk meningkatkan budaya keselamatan kerja di PT XYZ. Selain komitmen manajemen, peran serta pekerja juga menjadi penting karena menyumbang

Tabel 1. Hasil karakterisitik responden

\begin{tabular}{lc}
\hline \multicolumn{1}{c}{ Karakteristik } & Persentase \\
\hline Jabatan & \\
Jabatan Manajer & $1,4 \%$ \\
Assistant Manajer & $6,8 \%$ \\
Supervisor & $9,6 \%$ \\
Staff & $21,9 \%$ \\
Operator/Teknisi & $52,1 \%$ \\
Jabatan lainnya & $8,2 \%$ \\
Usia & \\
$<25$ th & $5,5 \%$ \\
$25-30$ th & $13,7 \%$ \\
$30-35$ th & $17,8 \%$ \\
$35-40$ th & $13,7 \%$ \\
$40-45$ th & $23,3 \%$ \\
$45-50$ th & $21,9 \%$ \\
$>55$ th & $4,1 \%$ \\
\hline
\end{tabular}

tiga pernyataan dalam sepuluh pernyataan dengan gap tertinggi. Berdasarkan analisis yang dilakukan, terdapat beberapa hal yang menjadi perhatian utama untuk peningkatan budaya keselamatan kerja, antara lain:

- Komitmen manajemen untuk mengajak dan menghargai pekerja yang berpartisipasi dalam melaporkan kejadian yang hampir menyebabkan kecelakaan (near-miss accidents).

- Komitmen manajemen untuk memprioritaskan aspek keselamatan kerja dan pemberian konsekuensi bagi perilaku yang berbahaya.

- Komitmen manajemen untuk memastikan proses investigasi kecelakaan kerja bertujuan untuk mencari penyebab akar penyebab permasalahan untuk dilakukan perbaikan dan tidak berfokus pada penghukuman.

- Komitmen manajemen untuk meningkatkan kompetensi pekerja berkaitan dengan keselamatan.

- Komitmen manajemen dalam komunikasi dan sosialisasi keselamatan kerja di area operasi.

- Pemberian penghargaan dan konsekuensi aspek keselamatan kerja agar dijalankan secara konsisten.

- Tanggung jawab keselamatan kerja secara eksplisit dimasukkan ke dalam uraian tugas dan tanggung jawab pekerja.

\begin{tabular}{lc}
\hline \multicolumn{1}{c}{ Karakteristik } & Persentase \\
\hline Jenis kelamin & \\
Pria & $94,5 \%$ \\
Wanita & $5,5 \%$ \\
Pengalaman Kerja & \\
$<2$ tahun & $8,2 \%$ \\
$2-5$ tahun & $31,5 \%$ \\
$5-10$ tahun & $50,7 \%$ \\
$10-15$ tahun & $4,1 \%$ \\
$15-20$ tahun & $0 \%$ \\
$>20$ tahun & $5,5 \%$ \\
Pendidikan & \\
SLTA & $17,8 \%$ \\
Diploma & $43,8 \%$ \\
S1 & $4,3 \%$ \\
S2 & $34,2 \%$ \\
\hline
\end{tabular}


Faktor Perilaku yang Berpengaruh terhadap Budaya Keselamatan Kerja

Hasil analisis SEM menunjukkan bahwa model telah mencapai tingkat kesesuaian yang tinggi. Hal ini dapat dilihat dari nilai P-value (nilai P) sebesar 0,000 dan nilai RMSEA sebesar 0,031 sehingga dapat dikatakan bahwa model SEM yang dibuat telah mencapai Goodness of Fit yang baik. Penelitian ini menggunakan satu laten eksogen faktor perilaku dan terdiri dari beberapa lima peubah indikator yaitu X1, X2, X3, X4 dan X5. Kontribusi masing-masing variabel indikator pada laten eksogen terhadap variabel laten endogen $Y$ pada Tabel 2. Selanjutnya, model struktural dan nilai loading factor dari data yang telah diolah ditampilkan pada Gambar 1.

Tabel 2 menunjukkan bahwa semua peubah indikator memberikan kontribusi terhadap pembentukan laten eksogen faktor perilaku. Kontribusi terbesar adalah X5 terhadap Y yaitu dengan total kontribusi sebesar 0,4165 . Faktor peran pengawas memiliki pengaruh yang penting dalam pembentukan budaya keselamatan kerja karena peran pengawas sebagai panutan bagi bawahannya dan memberikan arahan yang jelas. Selain itu pengawas merupakan manajemen lini yang merupakan perpanjangan tangan dari manajemen dalam meneruskan kebijakan perusahaan. Hal ini relevan dengan pendapat dari Gibson (1996) yang menyatakan bahwa proses internalisasi budaya keselamatan kerja dapat dipercepat dengan melaksanakan fungsi manajerial. Manajerial melalui fungsi perencanaan, perngorganisasian, pengarahan dan pengendalian dapat mengubah budaya dan hal ini harus dilaksanakan secara konsisten. Beberapa penelitian yang dilakukan oleh Boughaba et al. (2014), Habibi dan Fereidan (2009) serta Morrow et al. (2014) menunjukkan perananan penting manajemen di dalam pembentukan budaya keselamatan kerja dan peranan ini ditunjukkan oleh pengawas. Kontribusi terendah adalah X3 terhadap Y, yaitu dengan total kontribusi sebesar 0,2548. Faktor persepsi terhadap perilaku aman memberikan kontribusi terendah karena persepsi merupakan pendapat pekerja terkait dengan kondisi di tempat kerjanya dihubungan dengan potensi terjadinya kecelakaan kerja. Beberapa responden menunjukkan persepsi bahwa lingkungan kerja dan peralatan kerja tidak memiliki potensi dalam menimbulkan kecelakaan kerja. Untuk melihat dan mengetahui apakah semua koefisien jalur (lintas) signifikan atau tidak maka digunakan statistik uji-t yang hasilnya ditampilkan di Gambar 2 .

Tabel 2. Kontribusi peubah indikator terhadap laten eksogen

\begin{tabular}{|c|c|c|c|}
\hline Indikator & Faktor muatan & Koefisien kontruksi & Kontribusi \\
\hline $\mathrm{X} 1$ (pengetahuan mengenai perilaku aman) & 0,53 & & 0,2597 \\
\hline X2 (motivasi berperilaku aman) & 0,58 & 0,49 & 0,2842 \\
\hline X3 (persepsi terhadap perilaku aman) & 0,52 & & 0,2548 \\
\hline X4 (peran rekan kerja) & 0,77 & & 0,3773 \\
\hline X5 (peran pengawas) & 0,85 & & 0,4165 \\
\hline
\end{tabular}

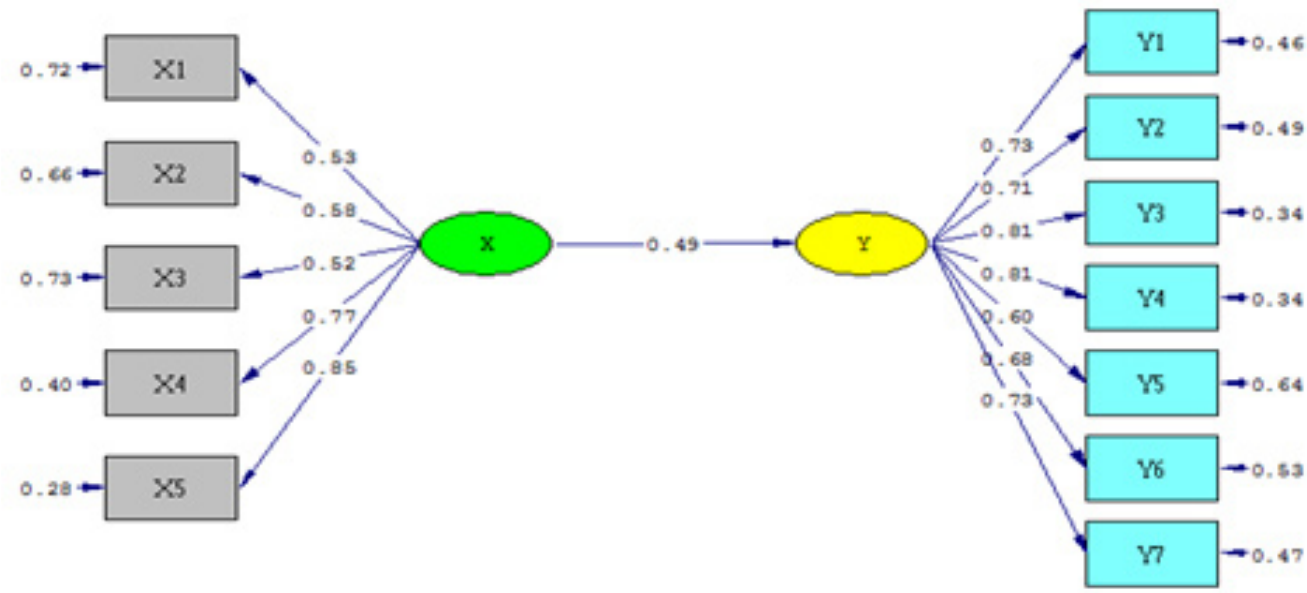

Ch1-Square $=98.73, \mathrm{df}=44, \mathrm{P}-\mathrm{value}=0.00000$, RMSEA $=0.031$

Gambar 1. Path diagram hasil estimasi faktor muatan (loading factor) model struktural 
Gambar 3 menunjukkan bahwa tidak terdapat koefisien jalur yang berwarna merah dan nilai-nilai yang diperoleh seluruhnya lebih besar dari t-hitung 1,96 yang merupakan nilai t-kritis dengan taraf nyata sebesar 0,05 , sehingga dapat disimpulkan bahwa seluruh koefisien jalur sudah signifikan (Suharjo dan Suwarno, 2002). Untuk mengetahui kriteria kesesuaian model SEM maka dalam penelitian ini menggunakan enam Index kesesuaian dan cut off value yang biasa digunakan untuk menguji kecocokan model secara keseluruhan. Nilai dari keenam kriteria Goodness of Fit dapat dilihat pada Tabel 3 .

Pengujian hipotesis dilihat dari besarnya nilai kritis uji-t statistik. Berdasarkan pengujian yang dilakukan diperoleh nilai t hitung sebesar 3,63 dan sudah lebih besar dari t table. Oleh sebab itu, dapat disimpulkan bahwa H1, yakni Faktor perilaku berpengaruh positif dan signifikan terhadap budaya keselamatan kerja, dapat diterima dan sebaliknya H0 ditolak. Peneliti belum menemukan studi yang meneliti hubungan antara perilaku aman terhadap budaya keselamatan kerja. Namun berdasarkan studi literatur, hasil penelitian yang dilakukan penulis telah sesuai dengan Geller (2001) yang menyatakan perilaku aman merupakan salah satu faktor yang membentuk budaya aman.

Hasil penelitian juga sesuai dengan penelitian Boughaba et al. (2014) yang menemukan pelatihan keselamatan penting dalam meningkatkan budaya keselamatan dan pelatihan keselamatan membentuk pengetahuan mengenai perilaku aman. Penelitian pendukung lainnya dilakukan oleh Habibi dan Fereidan (2009) yang menemukan faktor pelatihan dan kompetensi, keterlibatan pekerja dalam keselamatan dan kesehatan kerja, pengawas, prosedur keselamatan kerja, pandangan pekerja terhadap kondisi budaya keselamatan kerja berpengaruh terhadap budaya keselamatan kerja. Penelitian pendukung lainnya dilakukan oleh Cabrera et al. (2007) yang menemukan motivasi dan program pelatihan memengaruhi budaya keselamatan kerja. Penelitan lainnya dilakukan oleh Morrow et al. (2014) yang menemukan tanggung jawab pengawas, tanggung jawab personel, kualitas pelatihan memengaruhi budaya keselamatan kerja.

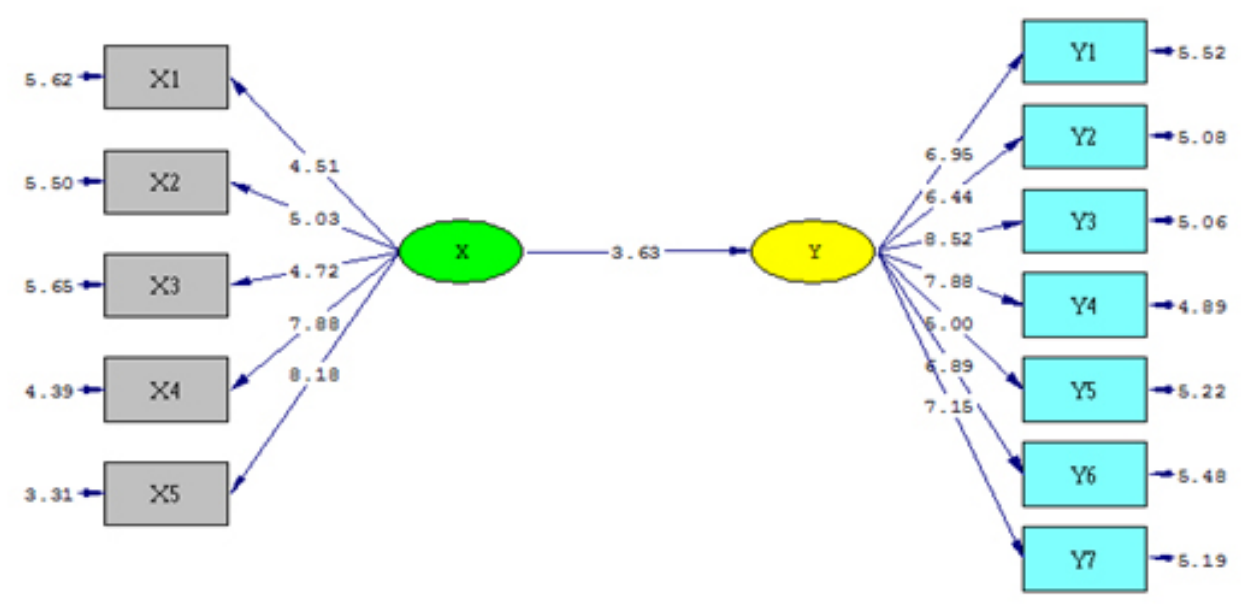

Chi-Square $=98.73, \mathrm{df}=44, \mathrm{p}-\mathrm{value}=0.00000, \mathrm{RuSEA}=0.031$

Gambar 2. Hasil statistik uji-t

Tabel 3. Hasil kriteria kesesuaian model SEM

\begin{tabular}{lccc}
\hline \multicolumn{1}{c}{ Goodness-of-Fit } & Cut-off-Value & Hasil & Keterangan \\
\hline Derajat bebas (DF) & Positif & 44 & Good fit \\
Chi-Square ( $\chi 2)$ & Harus kecil & 98,73 & Good fit \\
RMSEA (Root Mean Square Error of Approximation) & $\leq 0,08$ & 0,031 & Good fit \\
GFI (Goodness of Fit) & $\geq 0,90$ & 0,95 & Goodfit \\
AGFI (Adjusted Goodness of Fit Index) & $\geq 0,90$ & 0,91 & Good fit \\
CFI (Comparative Fit Index) & $\geq 0,90$ & 0,97 & Good fit \\
\hline
\end{tabular}




\section{Strategi Meningkatkan Budaya Keselamatan Kerja PT XYZ}

PT XYZ telah menjadikan keselamatan kerja menjadi priotitas utama di dalam menjalankan operasinya. Hal ini tertuang di dalam visi misi perusahaan dan menjadikan HSSE (Health Safety Security and Environment) sebagai salah satu dari empat aspek yang menjadi fokus dari strategi utama perusahan, yakni people, process, technology and environment approach. Pengelolaan keselamatan kerja menjadi bagian dari rencana jangka panjang (RJP) perusahaan dan diturunkan ke dalam delapan program keselamatan kerja, terdiri atas penerapan reward dan punishment, reorganisasi departemen HSSE sebagai advisor, penerapan HSSE passport, penerapan sistem manajemen keselamatan kerja kontraktor, pemenuhan peralatan penanggulangan kebakaran sesuai standar, penerapan 7 elemen keselamatan operasi fundamental operation excellence dan penerapan sistem manajemen QHSE (Quality, Health, Safety and Environment) secara konsisten. Delapan program keselamatan kerja tersebut terkait dengan budaya keselamatan kerja, baik langsung atau tidak langsung.

Kombinasi dari hasil gap analisis dan analisis SEM, peneliti merekomendasikan beberapa program bagi PT XYZ guna peningkatan budaya keselamatan kerja di perusahaan. Program pertama adalah memperkuat komitmen manajemen untuk meningkatkan aspek keselamatan kerja dan menjadikan aspek keselamatan kerja menjadi prioritas. Komitmen tersebut harus diwujudkan secara nyata dan konsisten. Program ini sesuai dengan hasil gap analisis pada elemen pertama budaya keselamatan kerja dan berhubungan dengan indikator kelima dari faktor perilaku aman. Hal ini didukung oleh hasil penelitian Andi (2008), Hale et al. (2010), dan Jacob et al. (2014) yang menunjukkan dalam membangun budaya keselamatan kerja dibutuhkan komitmen dari manajemen.

Program kedua adalah memastikan proses investigasi setiap insiden agar dilakukan secara objektif guna mencari akar penyebab permasalahan dan tidak berfokus pada pelaku yang bersalah. Hal ini juga masih berkaitan dengan komitmen dari manajemen untuk menciptakan keadilan dan memacu setiap orang untuk terbuka melaporkan kondisi tidak aman dan perilaku tidak aman. Program ini sesuai dengan hasil gap analisis pada elemen ketiga budaya keselamatan kerja dan berhubungan dengan indikator kelima dari faktor perilaku aman.

Program ketiga adalah mempertahankan program penghargaan dan konsekuensi atas upaya dan pencapaian aspek keselamatan kerja. Guna memacu pekerja memberikan kontribusi atas aspek keselamatan kerja maka aspek keselamatan kerja agar dimasukkan ke dalam uraian tugas dan tanggung jawab jabatan dan ukuran kinerja individu. Program ini berkaitan dengan upaya mempromosikan aspek keselamatan kerja bagi setiap individu. Program ini sesuai dengan hasil gap analisis pada elemen pertama dan elemen kedua budaya keselamatan kerja dan berhubungan dengan indikator pertama dan kedua dari faktor perilaku aman. Hal ini sejalan dengan hasil penelitian Jacob et al. (2014) bahwa kebijakan promosi keselamatan kerja berpengaruh pada peningkatan budaya keselamatan kerja.

Program keempat adalah memastikan setiap personil telah dibekali dengan kompetensi keselamatan kerja yang memadai sesuai dengan kebutuhan jabatan dan risiko pekerjaan. Program ini sesuai dengan hasil gap analisis pada elemen dua dan tujuh budaya keselamatan kerja dan berhubungan dengan indikator pertama dari faktor perilaku aman Hal ini didukung oleh hasil penelitian Jacob et al. (2014) yang menunjukkan pengetahuan pekerja berpengaruh pada peningkatan budaya keselamatan kerja.

Program kelima adalah komunikasi aspek keselamatan kerja berupa tool box safety meeting, rapat kerja keselamatan agar disusun sampai ke level ujung tombak, dijalankan secara konsisten dan terdokumentasi serta dimonitor pelaksanaannya. Komunikasi agar berlangsung dua arah sehingga masing-masing pihak dapat menyampaikan aspirasinya. Program ini sesuai dengan hasil gap analisis pada elemen dua dan enam budaya keselamatan kerja dan berhubungan dengan indikator pertama, keempat dan kelima dari faktor perilaku aman. Hal ini sejalan dengan hasil penelitian dari Hale et al. (2010) yang menunjukkan bahwa dialog yang konstruktif antara pekerja ujung tombak dan manajemen lini memberikan dampak positif bagi budya keselamatan kerja

Program kelima berupa analisis beban kerja dan kecukupan jumlah personil guna memastikan bahwa setiap pekerjaan dapat dilakukan pengawasan secara 
cukup dan mengantisipasi kekurangan jumlah pengawas dan faktor kelelahan. Program ini sesuai dengan indikator kelima dari faktor perilaku aman.

Program terakhir adalah sosialisasi HSE golden rules (patuh, intervensi dan peduli) agar digiatkan dan didukung dengan penerapan SWA (stop work authority) guna memastikan setiap orang memilkiki hak untuk mengintervensi dan menghentikan kondisi atau perilaku yang tidak aman. Program ini sesuai dengan hasil gap analisis pada elemen empat, lima dan enam budaya keselamatan kerja dan berhubungan dengan indikator dua, tiga dan empat dari faktor perilaku aman

\section{Implikasi Manajerial}

Beberapa hal yang dapat dijadikan arahan kebijakan bagi manajemen PT XYZ adalah secaran teoritis hasil penelitian ini merupakan bukti empiris terhadap teori yang menyatakan faktor perilaku berkontribusi terhadap terbentuknya budaya keselamatan kerja. Budaya keselamatan kerja yang meningkat diharapkan dapat meningkatkan kinerja keselamatan kerja. Informasi ini sangat penting bagi manajerial untuk menentukan strategi pengelolaan keselamatan kerja. Penelitian ini dapat dijadikan sebagai acuan oleh manajemen PT XYZ dalam melakukan kegiatan peningkatan budaya keselamatan kerja dengan cara mereview dan menyempurnakan kebijakan keselamatan kerja, memperkuat komunikasi keselamatan kerja sampai ke ujung tombak, penyempurnaan uraian tugas dan jabatan setiap pekerja, penyempurnaan mekanisme penilaian kinerja individu, penyiapan sumber daya untuk meningkatkan kompetensi pekerja dan menyempurnakan sistem tata kerja dari setiap kegiatan operasional.

\section{KESIMPULAN DAN SARAN}

\section{Kesimpulan}

Hasil penelitian diperoleh kesimpulan bahwa budaya keselamatan kerja di PT XYZ masih belum sesuai dengan yang diharapkan. Faktor perilaku yang terdiri dari pengetahuan mengenai perilaku aman, motivasi berperilaku aman, persepsi terhadap perilaku aman, peran rekan kerja dan peran pengawas memiliki pengaruh yang signifikan dalam membentuk budaya keselamatan kerja di PT XYZ. Oleh sebab itu, harus dilakukan strategi guna meningkatkan budaya keselamatan kerja di perusahaan dengan fokus kepada komitmen manajemen, implementasi program reward dan konsekuensi, sosialisasi HSE golden rules (patuh, intervensi dan peduli), penerapan SWA (stop work authority), komunikasi keselamatan kerja, partisipasi pekerja dalam aspek keselamatan, dan pemenuhan kompetensi aspek keselamatan kerja.

\section{Saran}

Penelitian ini menjadi sebuah awalan untuk pengembangan penelitian selanjutnya agar analisis yang ditelaah dapat dilakukan dengan lebih mendalam. Untuk selanjutnya, disarankan adanya penelitian terhadap beberapa lapangan di PT XYZ sehingga diharapkan memberikan analisis yang lebih akurat mengenai budaya keselamatan kerja di PT XYZ. Selain itu akan lebih baik bila dilakukan penelitian terhadap beberapa perusahaan yang bergerak di sektor hulu migas untuk dapat memberikan analisis yang lebih akurat mengenai budaya keselamatan kerja pada sektor hulu migas di Indonesia.

\section{DAFTAR PUSTAKA}

Aisah S. 2011. Analisis tingkat kepuasan komunikasi karyawan dan hubungannya dengan produktivitas kerja karyawan pada kantor pusat PT Bukit Asam (Persero) Tbk.[tesis]. Bogor: Institut Pertanian Bogor.

Amirah NA, Asma WI, Muda MS, Azis WA, Amin WM. 2013. Safety culture in combating occupational safety and health problems in the malaysian manufacturing sectors. Journal of Asian Social Science 9(3): 182-191. https://doi.org/10.5539/ ass.v9n3p182.

Andi. 2008. Construction workers perceptions toward safety culture. Journal of Civil Engineering Dimension 10(1): 1-6.

Boughaba A, Hassane C, Roukia O. 2014. Safety culture assessment in petrochemical industry: a Comparative study of two Algerian plants. Journal of Safety and Health at Work 5: 60-65. https://doi.org/10.1016/j.shaw.2014.03.005.

Cabrera DD, Fernaud EH, Diaz Ri. 2007. An evaluation of a new instrument to measure organizational safety culture values and practices. Journal of Accident Analysis and Prevention 39: 1202 1211. https://doi.org/10.1016/j.aap.2007.03.005.

DeSarbo W, Benedetto A, Song M. 2007. A 
heterogeneous resource based view for exploring relationships between firm performance and capabilities. Journal of Modelling in Management 2(2): 103-124. https://doi. org/10.1108/17465660710763407.

Fabio B, Hubeis M, Puspitawati H.2016. Pengaruh gaya kepemimpinan, motivasi kerja terhadap komitmen organisasi yang berimplikasi pada kinerja karyawan. Jurnal Aplikasi Bisnis dan Manajemen 2(1): 91-104.

Ferdinand A. 2002.Structural Equation Modelling (SEM) dalam Penelitian Manajemen. Semarang: Badan Penerbit Universitas Diponegoro.

Geller ES. 2001. The Psycology of Safety Handbook. Washington DC: Lewis Publishers.

Gibson JL, Ivanevich JM, Donelly JH Jr. 1996. Organisasi. Edisi ke-8. Jakarta: Binarupa Aksara.

Habibi E, Fereidan M. 2009. Safety cultural assessment among management, supervisory and worker groups in a tar refinery plant. Journal of Research in Health Science 9(1): 30-36.

Hale AR, Guldenmund FW, Loenhout PLCHV, Oh JIH. 2010. Evaluating safety management and culture interventions to improve safety: effective intervention strategies. Journal of Safety Science 48: $\quad 1026-1035 . \quad$ https://doi.org/10.1016/j. ssci.2009.05.006.

Havold JI. 2010. Safety culture and safety management aboard tankers.Journal of Reliability Engineering and System Safety 95(5): 511-519. https://doi. org/10.1016/j.ress.2010.01.002.

Hee OC, Ping LL. 2014. Organizational culture and safety performance in the manufacturing companies in Malaysia: a conceptual analysis. International Journal of Academic Research in Business and Social 4(1): 99-107.

Istijanto. 2005. Riset Sumber Daya Manusia. Jakarta: Penerbit Gramedia Pustaka Utama.

Jacob A, Joseph J, Rengaraj M. 2014. Study of the influence of safety factors by performing factor analysis. International Journal of Engineering Trends and Technology (IJETT) 9(6): 272-276. https://doi.org/10.14445/22315381/IJETTV9P254.

Khdair WA, Shamsudin FM, Subramanim C. 2011. Improving safety performance by understanding relationship between management practices and leadership behavior in the oil and gas industry in
Iraq: a proposed model. International Conference on Management and Artificial Intelligence (IPEDR) 6: 85-94.

Kines P, Lappalainen J, Mikkelsen KL, Olsen E, Pousette A, Tharadsen J, Tomasson K, Törner M. 2011. Nordic safety climate questionnaire (NOSACQ-50): a new tool for diagnosing occupational safety climate. International Journal of Industrial Ergonomics 41: 634-646. https://doi.org/10.1016/j.ergon.2011.08.004.

Krebs KD. 2005. Can servant-leaders be safety indicators? development and test of a model linking servant leadership to occupational safety. [disertasi]. Chichago: College of Liberal Arts and Sciences DePaul University.

Kristanto YD, Fahmi I, Maulana A. 2017. Pengembangan kamus kompetensi keselamatan kerja di PT XYZ Indonesia Tbk. Jurnal Aplikasi Bisnis dan Manajemen 3(1): 1-11.

Mineral Council of Australia. 1999. Safety Culture Survey Report of The Australian Mineral Industry. AUS: SAFEmap

Morrow SL, Koves GK, Barnes VE. 2014. Exploring the relationship between safety culture and safety performance in U.S. nuclear power. Journal of Safety Science 69: 37-47. https://doi. org/10.1016/j.ssci.2014.02.022.

Nazir M. 1988. Metode Penelitian. Jakarta: Penerbit Ghalia Indonesia.

Pertamina EP. 2016. 2015. Integrated Annual Report. www.pertamina-ep.com. [02 Desember 2016].

Sialagan TR. 2008. Analisis faktor-faktor yang berkontribusi pada perilaku aman di PT EGS Indonesia [tesis]. Jakarta: Universitas Indonesia.

SKK Migas. 2016. Website SKKMigas. www.skkmigas. go.id.[02 Desember 2016].

Suharjo B, Suwarno. 2002. Linear Structural Relationship (LISREL). Teori dan Aplikasinya. Bogor: Jurusan MAtematika, FMIPA-IPB.

Takala J, Hamalainen P, Saarela KL, Yun LY, Manickam $\mathrm{K}$, Jin TW, Heng P, Tjong C, Kheng LG, Lim $\mathrm{S}$ et al. 2012. Global estimates of the burden of injury and illness at work in 2012. Journal of Occupational and Environmental Hygiene 11: 326-337. https://doi.org/10.1080/15459624.201 3.863131 .

Zulganef. 2006. Pemodelan Persamaan Struktur dan Aplikasinya Menggunakan AMOS 5. Bandung: Pustaka. 